\title{
COVID-19: Deciphering the cardiology riddle
}

\section{Tania Muñoz}

Critical Patients Unit. Metropolitan Hospital of Providencia. Santiago; Chile

Corresponding author: Tania Muñoz, Critical Patients Unit. Metropolitan Hospital of Providencia. Santiago; Chile

Received date: September 22, 2020; Accepted date: September 28, 2020; Published date: October 07, 2020

Citation: Tania Muñoz (2020) COVID-19: Deciphering the cardiology riddle. J, Clinical Cardiology and Cardiovascular Interventions, 3(8); Doi:10.31579/2641-0419/086

Copyright: () 2020 Tania Muñoz, This is an open access article distributed under the Creative Commons Attribution License, which permits unrestricted use, distribution, and reproduction in any medium, provided the original work is properly cited.

In this writing I propose pathophysiological mechanisms that could be altering the regulatory control of blood pressure and heart rate of patients hospitalized in ICU for COVID-19, through clinical observation, monitoring and measurements of non-invasive hemodynamic variables, in a series of patients. In this disease, it's common to find: sustained elevation of systolic blood pressure (SBP), diastolic blood pressure (DBP) in the normal range and even slightly decreased, thus keeping the mean arterial pressure (MAP) above $65 \mathrm{mmHg}$. The SBP value depends on: blood volume, stroke volume (SV) and aortic compliance. [1] Echocardiography allows evaluating these variables with the $\mathrm{E} / \mathrm{E}$ 'ratio, continuity equation and two-dimensional visualization of the aorta artery [2]. It was observed that this series: E / E 'ratio, at the lower limit of normality or decreased, possibly because a neutral or negative fluid balance is sought in the management of respiratory distress. It was constant to evaluate that the SV was within the normal range, proposing aortic compliance as the determinant of the increase in SBP. Note that this alteration wouldn't be striking in elderly patients due to aortosclerosis, but it would be in younger patients. Several studies have indicated that the SARS CoV2 virus produces an aggressive activation of the inflammatory cascade, [3] causing important damages such as: pneumonitis, myocarditis; very possibly aortitis and carotitis for being close to the heart. In measurements made by two-dimensional echocardiography, aortic root dilation wasn't observed in most of the younger patients, however, it would not rule out possible arterial inflammation. A striking finding was also the drop-in heart rate below $60 \mathrm{bpm}$ (sinus bradycardia), especially in cases of sudden onset.

Keeping the hypothesis line, I propose that after ruling out ischemic etiology, this could correspond to a dysfunctionality of the baroreceptor located in the carotid bulb and by contiguity it would affect the vagus or parasympathetic nerve, producing its manifest excitation in bradycardia and elevation of SBP. This inflammatory mechanism could also explain the presence of abrupt, jerky ventilatory mechanics observed in some patients with difficult coupling with the ventilator, since the phrenic nerve adjacent to the bulb innervates the diaphragm. It would also be the case of the recurrent laryngeal nerve, responsible for the phonation mechanism, its inflammation could contribute to the high incidence of speech disorders reported in these patients, in addition to the prolonged invasive ventilatory support.
Regarding the presence of tissue hypoperfusion evaluable from parameters such as: venous oxygen saturation, lactic acid and MAP, [4] this series didn't register a significant alteration - evaluable in the lactic acid and MAP series - probably for these reasons: a virus of rapid and numerous replication, would mainly cause more central damage (lung, heart and great arterial vessels) than peripheral; In addition, as the virus binds to ECA2 receptors internalizing them, the production of angiotensin 1-7 would decrease, increasing non-catalyzed angiotensin II and peripheral vasoconstriction would predominate despite the presence of vasodilator cytokines, a noncharacteristic scenario in sepsis of other etiologies. I should point out that the above are only hypotheses, based on the observation of a series of 60 patients, limited by the absence of invasive measurements (right heart catheterization), the implementation of a scientific methodology that doesn't exclude observational bias (a single observer) and the absence of anatomical and histopathological study. However, the pathophysiological bases were consistent and sustainable through echocardiographic measurements, invasive blood pressure monitoring, and analysis of paraclinical examinations.

\section{References:}

1. Guyton y Hall. Vascular compliance and functions in the arterial and venous systems. Treaty on medical physiology, $2016.13^{\text {a }}$ edition, Chapter 15: 165-176.

2. Lang RM, Badano LP, Mor-Avi V, Afilalo J, Armstrong A, Ernande $\mathrm{L}$ et al. Recommendations for cardiac chamber quantification by echocardiography in adults: an update from the American Society of Echocardiography and the European Association of Cardiovascular Imaging. Eur Heart J Cardiovasc Imaging 2015; 16:233-270.

3. Paramo J. Inflammatory response in relation to COVID and other prothrombotic phenotypes Reumatol clin, 2020.

4. Hernández G. y Salgado J. Monitoring tissue perfusion in the critically ill patient. Rev Cient Cienc Med 2016; 19(2): 43-47, 
(c) ()

This work is licensed under Creative

Commons Attribution 4.0 License

To Submit Your Article Click Here: Submit Article

DOI:10.31579/2641-0419/086
Ready to submit your research? Choose Auctores and benefit from:

* fast, convenient online submission

* rigorous peer review by experienced research in your field

* rapid publication on acceptance

* authors retain copyrights

* unique DOI for all articles

* immediate, unrestricted online access

At Auctores, research is always in progress.

Learn more www.auctoresonline.org/journals/clinical-cardiology-andcardiovascular-interventions 